\title{
The secondary effect of the first wave of COVID-19 and its consequences on myocardial infarction care in a high volume Hungarian cardiovascular centre
}

\author{
Réka Skodaa, Gábor Fülöpa, Emese Csulaka, Krisztina Danics ${ }^{b}$, Klára Törőb, \\ Laura Bokora, György Bárczi ${ }^{a}$, Béla Merkelya, Dávid Beckera
}

a Semmelweis University, Heart and Vascular Center, Budapest, Hungary

${ }^{b}$ Department of Forensic and Insurance Medicine, Semmelweis University, Budapest, Hungary

ARTICLE INFO

Article history:

Submitted: 2. 11. 2020

Accepted: 3. 11. 2020

Available online: 7. 7. 2021

Klíčová slova:

Akutní koronární syndrom COVID-19
SOUHRN

Úvod: Vysoký počet prípadů onemocnění COVID-19 klade vysoké nároky na zdravotnické systémy. V zemích těžce postižených pandemií uvádějí lékaři méně pacientů přivážených do nemocnic s akutními koronárními syndromy (AKS). Znepokojující je skutečnost, že u pacientů s život ohrožujícím onemocněním mưže docházet k více komplikacím, případně mohou zemřít na infarkt myokardu.

Informací o péči o jedince s AKS v zemích méně postižených pandemií je málo. Vzhledem $k$ tomu, že do této skupiny zemí patří Mad'arsko, bylo naším cílem posoudit změny v péči o jedince s infarktem myokardu na největším pracovišti v zemi, které provádí perkutánní koronární intervence.

Metody: Byly analyzovány výsledky cekem 512 po sobě následujících pacientů; z tohoto počtu jich 396 bylo ošetřeno v letech 2018 a 2019 ve srovnání se 116 jedinci s AKS v roce 2020 během pandemie. V naší studii jsme porovnali demografické a klinické charakteristiky pacientů i počty úmrtí mimo nemocnici v době před vypuknutím pandemie a v jejím průběhu.

Výsledky: Během pandemie došlo k $41 \%$ (116/298) poklesu počtu všech AKS a k 29\% snížení počtu pacientů s infarktem myokardu s elevacemi úseku ST (STEMI) (61/87) i 51\% snížení počtu pacientů s infarktem myokardu bez elevací úseku ST (NSTEMI) (54/111). Podíl pozdě prijiatých pacientů se STEMI pritom vzrostl (17,49 \%, 18/105 vs. $34,48 \%, 10 / 29)$. Zaznamenali jsme i pokles v počtu těžkých případů, intervencí na kmeni levé věnčité tepny i pacientů s vysoce rizikovým NSTEMI. Úmrtnost mimo nemocnici vzrostla o $17 \%$.

Závěr: I když v první vlně byl mad'arský zdravotnický systém pandemií méně zasažen, pozorovali jsme významný pokles v počtu prípadů AKS. Opožděné poskytnutí péče nebo její naprostá absence mohou mít závažné důsledky pro prognózu pacienta. Vzhledem ke zvyšujícím se počtům případů onemocnění COVID-19 ve druhé vlně nabývá na významu nutnost zvýšit povědomí pacientů i zdravotnických pracovníků o nezbytnosti časného poskytnutí péče jedincům s AKS.

(c) 2021, ČKS.

\section{ABSTRACT}

Introduction: The high number of COVID-19 cases lean much burden on the healthcare system. Physicians report fewer acute coronary syndrome (ACS) patients presenting to hospitals in countries severely affected by the pandemic. It is concerning that patients with life-threatening illness can suffer more complications or die due to their myocardial infarction.

We have limited information about ACS-care in countries less affected by the pandemic. Being Hungary one of them, we aimed to investigate the changes in myocardial infarction care in the country's biggest PCl-center. Methods: A total of 512 consecutive patients have been investigated, 396 people have been treated in 2018 and 2019 compared to 116 subjects suffering ACS in 2020 during the pandemic. We compared patients' demographical and clinical characteristics as well as out-of-hospital death rates before versus during COVID-19 outbreak. Results: A $41 \%$ (116/298) decrease in total ACS cases, a 29\% (61/87) decline in STEMI and 51\% (54/111) in NSTEMI patients could be witnessed during the pandemic. The proportion of STEMI patients admitted late $(17.49 \%, 18 / 105$ vs. $34.48 \%, 10 / 29)$. The number of severe cases - LM intervention, very high risk NSTEMI decreased. Out-of-hospital mortality increased by $17 \%$.

Conclusion: Although the Hungarian healthcare system in the first wave was less burdened by the pandemic we saw a significant decline in ACS cases. The hazards of the delayed or lacking care can have a serious effect on the prognosis of these patients. Seeing the increasing number of COVID-cases in the second wave, it is even more important to raise awareness among patients and healthcare workers that ACS patients need to be treated.
Keywords:

Acute coronary syndrome COVID-19 


\section{Introduction}

The SARS-COVID-19 pandemic counts more than 3.5 million confirmed cases and about 250000 deaths worldwide by the time we closed our analysis, by 30th April 2020. ${ }^{1}$ In Hungary the numbers are 1882 confirmed cases, 312 deaths. Severe cardiovascular complications are one of the most common causes leading to death. That is why patients suffering from chronic cardiovascular diseases are at higher risk.

Physicians report that there are fewer acute coronary syndrome (ACS) patients presenting to hospitals during the pandemic. There is a concern that patients with ACS are presenting later to the Emergency Departments. Without proper, on time cardiac care unnecessary mortality rates can increase. Delays can lead to LV systolic dysfunction, cardiogenic shock, mechanical complications in short term. Long-term complications of the delay, such as suboptimal revascularization, worse remodelling, chronic heart failure, higher likelihood of developing arrhythmias can affect the prognosis of these patients.

Although it's known that SARS-CoV-2 raises the risk of thrombosis, there is a STEMI-paradox during the pandemic. A Spanish study involving 73 cardiac centres reports $40 \%$ decrease in STEMI patients. ${ }^{2}$ Americans report $38 \%$ reduction in catheterization due to STEMI. ${ }^{3}$ A multicentre, nationwide, observational study in Italy states a reduction in both STEMI by $26.5 \%$ and NSTEMI by $65.1 \%{ }^{4}$

There are some possible reasons for the decrease in ACS cases. During the pandemic patients are less likely to seek medical attention, they fear being admitted to a hospital. Besides patient's anxiety there was a significant delay on the part of the care providers. During the pandemic the safety measures can slow down the usual process. ${ }^{5}$ According to new guidelines, there was a change of threshold referring patients to cardiac catheterization. ${ }^{6}$

Besides the decrease in ACS cases, an increase in sudden cardiac death - outside of a hospital - can be detected. In Lodi, one of the most affected regions, the numbers of sudden cardiac death cases have risen by $183 \%{ }^{7}$
Seeing the decline in the number of patients with a life-threatening condition, we aimed to examine the situation in Hungary where the number of infected patients needing hospitalization and the mortality rates are not that high compared to those in Italy or Spain.

\section{Methods}

A total of 116 patients were admitted to our institute between 26.02.-22.04.2020. These cases were compared to those 396 ACS patients who had been treated in 2018 and 2019 in the same period (26.02.-22.04). We chose the starting date to be 26.02 . because that was the first week when we saw a significant decrease in ACS cases (Fig. 1).

For the diagnosis of STEMI, a clinical presentation typical of ongoing myocardial ischaemia, ST-segment elevation in at least 2 consecutive leads on the 12-lead electrocardiogram (ECG), and subsequent confirmation by elevation of necrosis markers was required. The diagnosis of NSTEMI and the differentiation between the NSTEMI groups was based on the Guideline of the European Society of Cardiology on the management of Acute Coronary Syndromes (ACS) in Patients presenting without persistent ST-segment Elevation. ${ }^{8}$ We sorted NSTEMI patients into very high risk and high risk infarction groups, being said that NSTEMI alone is already considered to be high risk. Those patients were enrolled to the very high risk group who had NSTEMI and either CX intervention (having deep ST-depression in the thoracic leads on ECG) or heart failure, cardiogenic shock or malignant arrhythmia due to their infarction.

Demographic and clinical patient data of these consecutive patients have been collected from the medical database of our institution and from the database of the Hungarian Central Statistical Office. Results are expressed as mean \pm standard deviation of mean (SD) and sample size $(n)$ for each treatment group of normal distribution. The level of significance was $\alpha=0.05$.

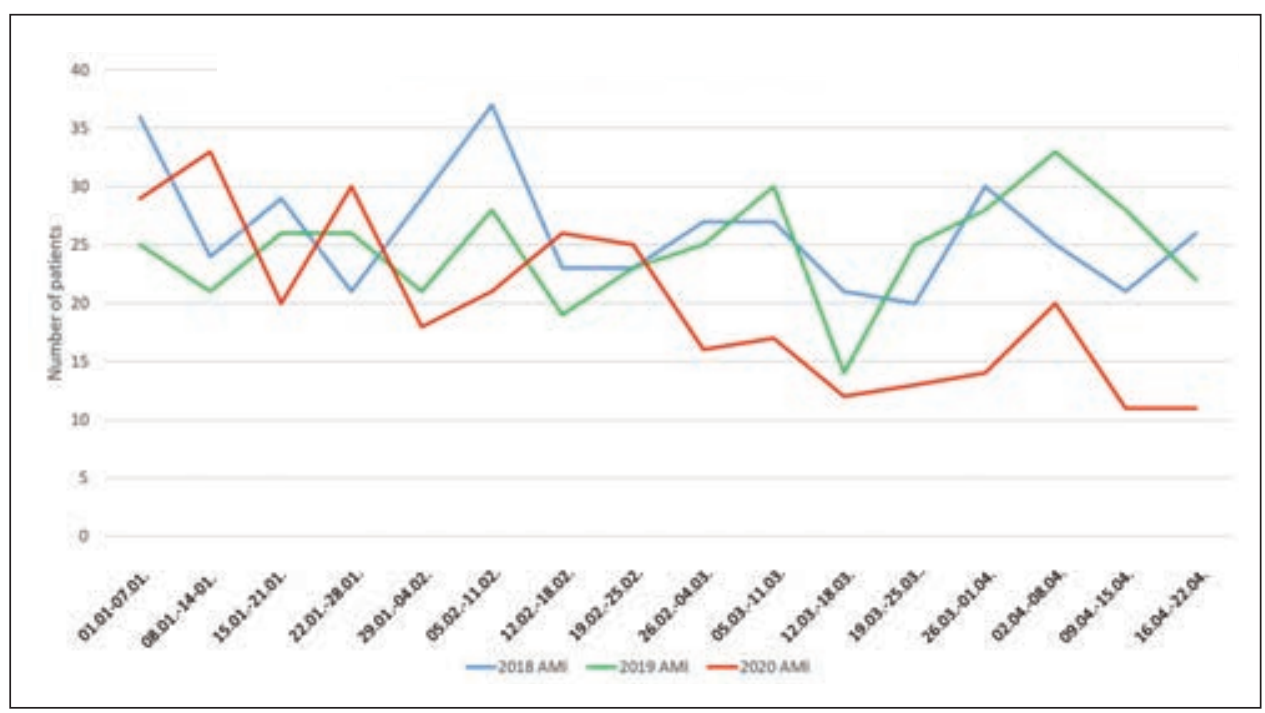

Fig. 1 - Weekly distribution of acute coronary syndrome cases before (2018-2019) and during the first wave of the COVID-19 pandemic (2020). 


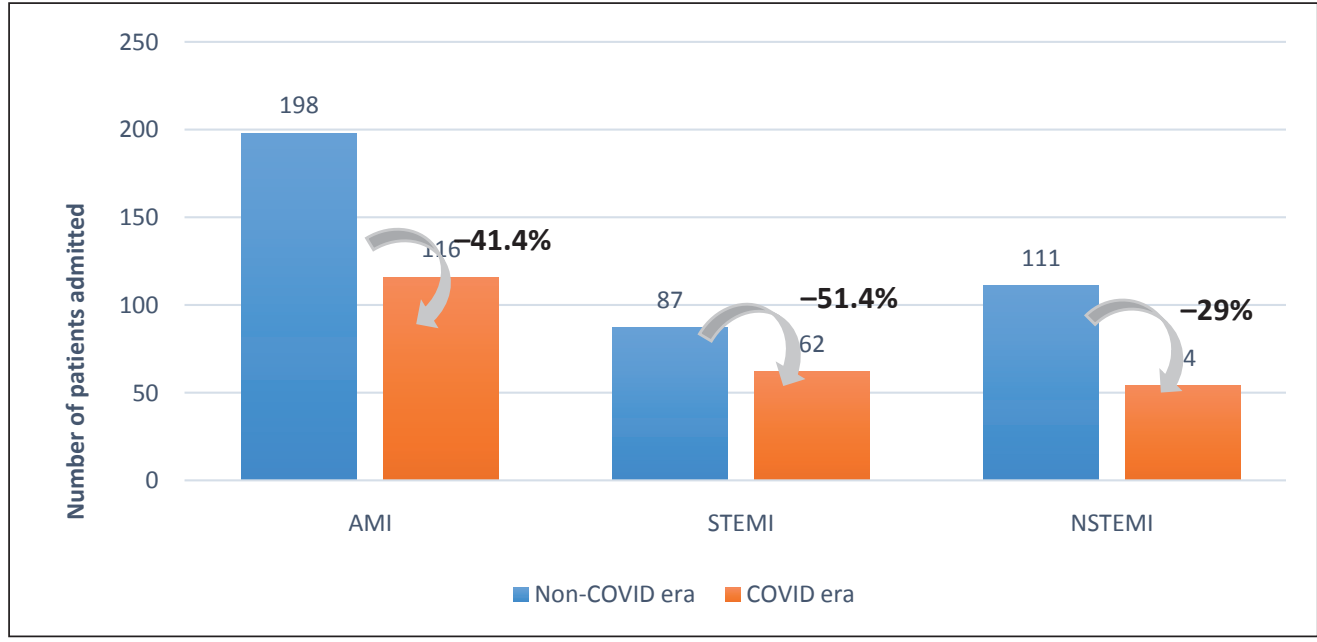

Fig. 2 - Dropping number of admissions during the first wave of the COVID-19 pandemic. AMI - acute myocardial infarction; NSTEMI - non ST-segment elevation myocardial infarction; STEMI - ST-segment elevation myocardial infarction.

\section{Results}

All of our patients have been tested and nobody was found COVID-19 positive considering an active infection.

We compared the numbers of MI cases in 2020 to the mean of 2018's and 2019's totals.

A 41.4\% decrease in ACS cases (116/298) can be noticed in 2020 compared to 2018-2019. Similar tendency can be seen examining the two different infarction types separately. ST-elevation myocardial infarction (STEMI) cases reduced by $29 \%(61 / 87)$. The decline in NSTE-ACS patients is more alarming, it is by $51.4 \%$ (54/111). The admission rates for myocardial infarction during the COVID-19 pandemic are presented in Figure 2.
Significant differences could be seen in the proportion of STEMI patients admitted late $(17.49 \%, 18 / 105$ vs $34.48 \%, 10 / 29)$ and in the type of the admission - from home by AMS $(40.66 \%, 161 / 396$ vs $54.31 \%, 63 / 116)$ or from another hospital (56.82\%, $225 / 396$ vs $41.38 \%$, 48/116). The other parameters and clinical characteristics of the two patient groups - non-COVID era vs COVID era - are presented in Table 1.

One of the main differences between the non-COVID and COVID era is that in $202073 \%$ of the patients were sent home directly compared to $38 \%$ in 2018 and 2019.

The number of AMI cases dropped dramatically. We saw a decline in the proportion of the LM interventions before vs during the pandemic (STEMI: $6.29 \%, 10 / 159$ vs

Table 1 - Demography and clinical characteristics of patients before versus during COVID-19

\begin{tabular}{|c|c|c|c|}
\hline & Non-COVID era & COVID era & $p$ \\
\hline Male (\%) & $69.2 \%(274 / 396)$ & $62.07 \%(72 / 116)$ & 0.1248 \\
\hline Mean age (years) & $67.6 \pm 12.76$ & $68.1 \pm 11,6$ & 0.381 \\
\hline STEMI (\%) & $43.94 \%(174 / 396)$ & $53.45 \%(62 / 116)$ & 0.0987 \\
\hline Median STEMI time frame (h) & $4 \pm 14.6$ & $6 \pm 27.5$ & 0.0014 \\
\hline STEMI patients admitted late $>12 \mathrm{~h}(\%)$ & $17.14 \%(18 / 105)$ & $34.48 \%(10 / 29)$ & 0.1498 \\
\hline Admission from home or scene (\%) & $40.66 \%(161 / 396)$ & $54.31 \%(63 / 116)$ & 0.0323 \\
\hline Referred from another hospital (\%) & $56.82 \%(225 / 396)$ & $41.38 \%(48 / 116)$ & 0.0257 \\
\hline In-hospital death (\%) & $6.06 \%(24 / 396)$ & $6.03 \%(7 / 116)$ & 0.4988 \\
\hline STEMI-in hospital death (\%) & $7,47 \%(13 / 174)$ & $9,68 \%(6 / 62)$ & 0,4351 \\
\hline NSTEMI-in hospital death (\%) & $4,95 \%(11 / 222)$ & $1,85 \%(1 / 54)$ & 0,3492 \\
\hline Mean inpatient days & $3.4 \pm 3.4$ & $3.05 \pm 1.7$ & 0.1426 \\
\hline Proportion of patients sent home directly from our institute (\%) & $37.9 \%(141 / 372)$ & $73.39 \%(80 / 109)$ & $<0.0001$ \\
\hline Heart failure (\%) & $30.75 \%(119 / 387)$ & $38.79 \%(45 / 116)$ & 0.1642 \\
\hline VF $(\%)$ & $6.84 \%(27 / 395)$ & $9.48 \%(11 / 116)$ & 0.3903 \\
\hline Reanimation (\%) & $10.35 \%(41 / 396)$ & $8.62 \%(10 / 116)$ & 0.4351 \\
\hline
\end{tabular}

STEMI - ST-segment elevation myocardial infarction; VF - ventricular fibrillation. 


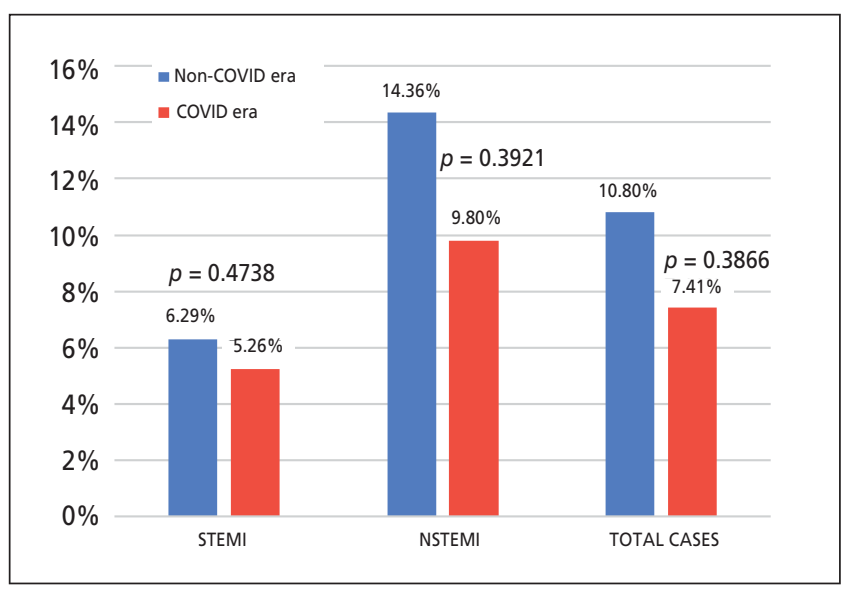

Fig. 3 - Percentage of LM interventions before and during the COVID-19 pandemic. LM - left main coronary artery; NSTEMI - non ST-segment elevation myocardial infarction; STEMI - ST-segment elevation myocardial infarction.

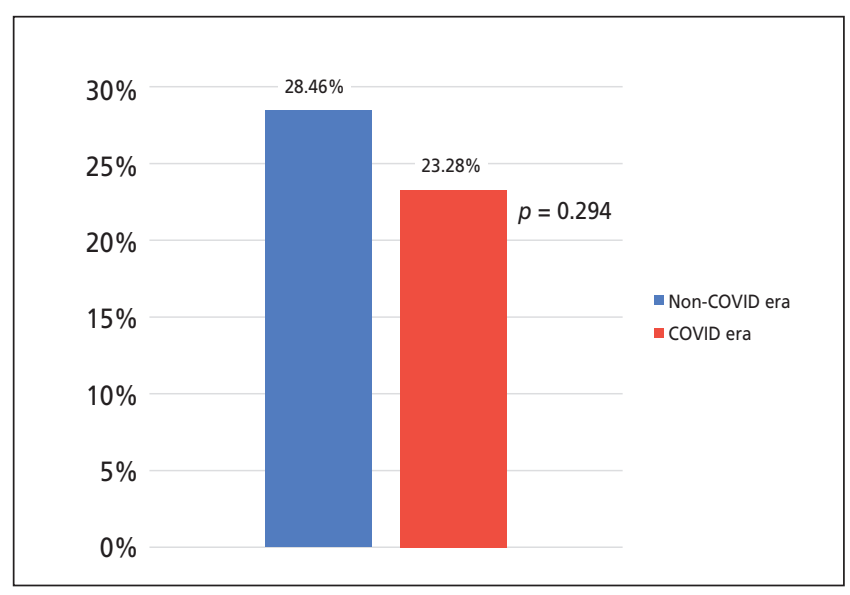

Figure 4 - Percentage of very high risk NSTEMI patients before and during the pandemic

$5.26 \%, 3 / 57$; NSTEMI: $14.36 \%, 29 / 202$ vs $9.8 \% 5 / 51)$ and in the number of very high risk NSTEMI patients $(28.46 \%$, $113 / 397$ vs $23.28 \%, 27 / 116)$. Our results are shown in Figures 3 and 4.

According to the results from the Hungarian Central Statistical Office the out of hospital mortality increased $(0.0641 \%$ vs $0.0808 \%)$ significantly in Central-Hungary representing our $\mathrm{PCl}$-centers provider territory.

\section{Discussion}

Similar to the numbers seen in Spain, Italy or in the USA ${ }^{2-4}$ we saw a serious decline in admission rates due to myocardial infarction. In these countries one of the main reasons for the delay was the overwhelmed healthcare system due to the daily raising numbers of new coronavirus cases.

Compared to the countries mentioned above, in Hungary the virus had a slower spread, the number of the confirmed cases and the mortality rates lags behind those in Italy or Spain. In Hungary the first COVID-19 positive patient was confirmed on 4th and the first patient died on 15th March. The government declared nationwide state of emergency on 11th March, restrictions on movement were announced on 27th March. But there was no action that would have affected the acute cardiac care. The highest number of new confirmed cases was 150 patients a day, the mean of the new confirmed cases was 46.25 daily. According to this data we can say that compared to other countries in the region and in Europe, in Hungary the number of the cases were moderate that would lean much burden on the healthcare system, patients with acute life-threatening illnesses can be treated with no delays as usual protocols recommend.

Our institute is the biggest interventional cardiology centre in Hungary handling high amount of patients about 2000 ACS cases a year -, and caring for almost one third of Hungary's population, ca 3 million citizens. So our data and results can represent Middle-Hungary or even the whole country.

Comparing infarction cases before and after COVID-19 era, we detected similar decrease in the numbers such as in Spain and Italy. It is alarming that $34.48 \%(10 / 29)$ STEMl patients were admitted late, 12 hours or later after the start of the symptoms in the COVID era, compared to $17.14 \%(18 / 105)$ in the non-COVID era. The prolonged timeframe caused higher in hospital mortality $(7.47 \%$ vs $9.68 \%$ ). Meanwhile the receptivity of our institution was constant.

According to the guidelines low risk NSTEMI cases can be managed medically and only high risk patients need to be transported to cath-lab. We suggested that during the pandemic high-risk patients are more likely to be admitted to catheterization. Studying the results of the coronary angiography there was no significant difference between LM interventions before vs during the COVID era. We examined whether during the pandemic it is more likely to treat very high risk NSTEMI patients. However, we saw a decline in LM interventions and the number of very high risk patients.

This year most ACS patients were treated the whole time in the same institute, there were less cases referred to another hospital or to rehabilitation facilities. UsuaIly patients are referred to another hospital - not interventional centre - for further evaluation. Knowing that COVID-19 infection had higher incidence in hospitals and healthcare facilities, we kept our patients away from transferring to another hospital. Despite the fact that this year most of the post infarction work up was made in our institute, the mean of the inpatient days did not differ from the data of the previous years. In the future we have to evaluate how this year's less patient education and less rehabilitation affect the compliance and post infarction-state.

The data suggests that because of the reasons mentioned above high number of $\mathrm{Ml}$ patients remained untreated. The increase seen in out-of-hospital mortality may support this theory. This rises attention to the fact that in extraordinary times, like a pandemic, proper patient information is even more important. We saw the decline in case numbers a week before the first COVID-19 positive case was confirmed in Hungary which supports that the mental impact of the pandemic precedes its actual clinical 
effect. Healthcare providers have to highlight those cases that are urgent and applying the safety protocols they have to be ready to treat these patients without delay.

\section{Conclusion}

The $40 \%$ drop of all ACS cases during the COVID-19 pandemic came with less high risk patients meaning less LM-interventions and less very high risk NSTEMI patients. So supposedly high number of patients remained untreated during the pandemic. Mortality rates, in the next few months, years, more complicated cases, more patients with heart failure, malignant arrhythmias can be expected due to their untreated infarction.

The pandemic has a serious secondary effect which will have an emphasized importance in the future. The hazards of the delayed care due to anxiety and other mental reasons should be stated among healthcare providers as well as population wise.

Seeing the rising number of cases in the second wave of the pandemic it is even more important to highlight this problem. With the epidemiologic precautions all ACS patients need to be treated according to the guidelines.

\section{Conflict of interest}

None declared.

\section{Funding body}

This study was supported by the National Research, Development and Innovation Office of Hungary (NKFIA; NVKP_16-1-2016-0017 National Heart Program). The research was financed by the Thematic Excellence Programme (Tématerületi Kiválósági Program, 2020-4.1.1.TKP2020) of the Ministry for Innovation and Technology in Hungary, within the framework of the Therapeutic
Development and Bioimaging programmes of the Semmelweis University.

\section{Ethical statement}

The study protocol conformed to the ethical guidelines of the 1975 Declaration of Helsinki.

\section{Acknowledgements}

Special thanks to Kinga Fülöp for her contribution.

\section{References}

1. Johns Hopkins University Coronavirus Resource Center, https:// coronavirus.jhu.edu/

2. Rodriguez-Leor O, Cid-Alvarez B, Ojeda S, et al. Impact of the COVID-19 pandemic on interventional cardiology activity in Spain. REC Interv Cardiol 2020;2:82-89.

3. Garcia S, Albaghdadi MS, Mejran PM, et al. Reduction in ST-segment elevation cardiac catheterization laboratory activations in the United States during COVID-19 pandemic. J Am Coll Cardiol 2020;75:2871-2872.

4. De Rosa S, Spaccarotella C, Basso C, et al. Reduction in hospitalizations for myocardial infarction in Italy in the COVID-19 era. Eur. Heart J 2020;41:2083-2088.

5. Tam CCF, Cheung KS, Lam S, et al. Impact of Coronavirus Disease 2019 (COVID-19) Outbreak on ST-Segment-Elevation Myocardial Infarction Care in Hong Kong, China. Circ Cardiovasc Qual Outcomes 2020;13:e006631.

6. ESC Guidance for the Diagnosis and Management of CV Disease during the COVID-19 Pandemic. https://www.escardio. org/Education/COVID-19-and-Cardiology/ESC-COVID-19Guidance.

7. Wendling P. Cardiac Arrests Out-of-Hospital Soar During COVID-19 in Italy. N Engl J Med. Published April 29, 2020 Letter.

8. Roffi M, Patrono C, Collet JP et al., ESC Scientific Document Group 2015 ESC Guidelines for the management of acute coronary syndromes in patients presenting without persistent ST-segment elevation: Task Force for the Management of Acute Coronary Syndromes in Patients Presenting without Persistent ST-Segment Elevation of the European Society of Cardiology (ESC). Eur Heart J 2016;37:267-315. 